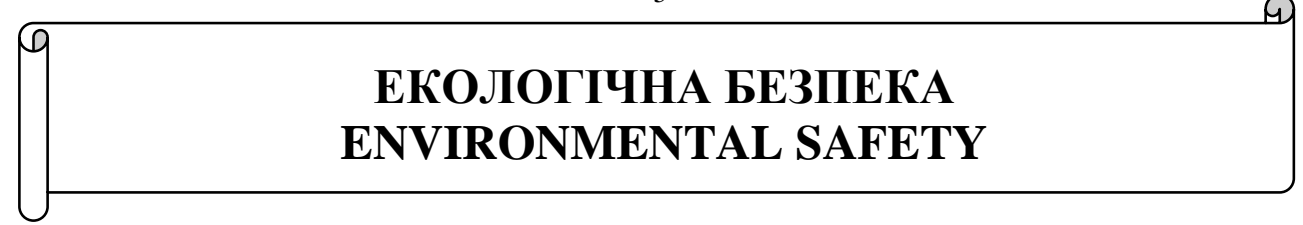

УДК 551.4

Oleh M. Adamenko, D. S., Professor, Honored Worker of Science and Technology of Ukraine, State Prize Laureate of the USSR

ORCID ID 0000-0003-0821-3011

Halyna D. Stelmakhovych, assistant of the department

ORCID ID 0000-0003-3148-5402 e-mail: o.stelmahovich@ukr.net

Mykola I. Mosiuk, PhD, Associate Professor

ORCID ID 0000-0002-9828-7331 e-mail: mosiuk@ukr.net

Ivano-Frankivsk National Technical University of Oil and Gas, Ivano-Frankivsk, Ukraine

\title{
TECHNOLOGICAL MAP OF THE STARUNSKY GEODYNAMIC LANDFILL ON THE PRYCARPATHIA
}

\begin{abstract}
Starunia's Geodynamic Landfill is an area of 60 hectares of the geological monument of nature of the national significance "Starunia" - the world-famous location of the Pleistocene mammoth fauna and four hairy rhinos. The first findings of the mummified carcasses of animals of the so-called mammoth fauna were found at a depth of $12 \mathrm{~m}$ at the mine (mine) for the extraction of ozokerite near the village. The old town of Bohorodchany district, Ivano-Frankivsk region, 1907 Scholars of Krakow and Lviv appreciated these unique discoveries enough and published a number of articles and a monograph in 1914. In 1929, an expedition of the Skill Academy from Krakow found the remains of three more hairy rhinos at a mine depth of $17 \mathrm{~m}$. Numerous bones of small vertebrates (rodents), shell remains, numerous species of insects, beetles, parasitic worms, bedbugs, butterflies, spiders, snails, vascular plants, midges, seeds and branches of dwarf birch, alder and other flora were also collected. Polish scientists have organized comprehensive studies of fauna and flora, partly their results were published in articles, but the Second World War halted this process. It is important to note that Starunia's findings intensified the comprehensive study of stratigraphy, paleontology, paleogeography, geochronology, and other aspects of the Quaternary - the quartet. It should be recalled that in 1932, in Leningrad, the International Geological Congress established INQUA - the International Union for the Study of the Quaternary. But the basic methodological foundations of this study were laid on the materials of Elder.
\end{abstract}

Keywords: geological monument of nature; environmental monitoring; geological environment; mammoth; rhino; techno-geological map; technosphere

(c) O.M. Adamenko, H.D. Stelmakhovych, M.I. Mosiuk, 2019 


\title{
О.М. Адаменко, Г.Г. Стельмахович, М.І. Мосюк
}

Івано-Франківський національний технічний університет нафти і газу, м. ІваноФранківськ, Україна

\section{ТЕХНОГЕОЛОГІЧНА КАРТА СТАРУНСЬКОГО ГЕОДИНАМІЧНОГО ПОЛІГОНУ НА ПРИКАРПАТТІ}

\begin{abstract}
Анотація. Старунський геодинамічний полігон - це територія площею 60 га геологічної пам'ятки природи загальнодержавного значення "Старуня» всесвітньо відоме місиезнаходження плейсточенової фауни мамонта та чотирьох волохатих носорогів. Перші знахідки муміфікованих туш тварин так званої мамонтової фауни були виявлені на глибині 12 м при проходиі копальні (щахти) для видобутку озокериту біля с. Старуні Богородчанського району Івано-Франківської області у 1907 рочі. Вчені Кракова і Львова достатньо оцінили ці унікальні відкриття і опублікували ряд статей та монографію у 1914 р. У 1929 р. експедичія Академї Вміння із Кракова при проходиі копальні на глибині 17 м знайшла рештки ще 3 волохатих носорогів. Були зібрані також численні кістки малих хребетних (гризунів), рештки мушлі, багатьох видів комах, жуків, паразитичних хробаків, блощиць, метеликів, павуків, слимаків, судинних рослин, мошок, насіння $і$ гілок карликової берези, вільхи та інших представників тундрової флори. Польські вчені організували комплексні вивчення фауни і флори, частково їх результати були опубліковані у статтях, але Друга світова війна призупинила цей прочес. Важливо відмітити, що Старунські знахідки інтенсифікували всебічне вивчення стратиграфії, палеонтологіï, палеогеографіï, геохронології та інших аспектів четвертинного періоду - квартету. Варто нагадати, щуо у 1932 рочі Міжнародний геологічний конгрес заснував INQUA - Міжнародний союз з вивчення четвертинного періоду. Але основні методичні засади иьього вивчення були закладені на матеріалах Старуні.
\end{abstract}

Ключові слова: геологічна пам'ятка природи; моніторинг довкілля; геологічне середовище; мамонт; носоріг; техногеологічна карта; техносфера

\section{Актуальність проблеми}

Природно-заповідний фонд України включає кілька категорій захисту довкілля: пам'ятки природи, заказники, регіональні ландшафтні парки, національні природні парки, природні та біосферні заповідники [4]. Оцінку екологічного стану їх складових компонентів та екологічної ситуації на площі об'єктів та територій пропонуємо виконувати методами моніторингу навколишнього середовища, який регламентується міжнародними стандартами і постановами Кабінету міністрів України та іншими директивними документами [1-3]. Для об'єктів природно-заповідного фонду категорії «пам'ятка природи», що мають, як правило, незначну площу, процедури моніторингу застосовуються вперше на прикладі геологічної пам'ятки природи загальнодержавного значення «Старуні». I першим етапом повинна стати техногеологічна карта як основа геоекологічно-антропогенної системи.

\section{Із історії досліджень}

Після перших знахідок мамонтової фауни у 1907 та 1929 рр. [9] вивчення Старуні відбувалось $з$ великими перервами $[14,15]$. 
У період між Першою і Другою світовими війнами, а також у післявоєнні 1945-1969 рр. на теренах Старуні і сусідніх площах розвідувались родовища озокериту (Старунське та Дзвиняцьке), які продовжували розроблятись, проводились інтенсивні пошуки нафти, але іiі родовища, у тому числі і у куполі Старунської складки, виявились занадто малими для промислової експлуатації [1].

У березні 1977 р. після землетрусу у горах Вранча (Румунія) на озокеритовому родовищі виник перший i поки що єдиний у Карпатах грязьовий вулкан, який додав Старунському палеонтологічному місцезнаходженню нового значення. Професори Івано-Франківського інституту нафти i газу доктори геолого-мінералогічних наук Надія Хрисанфівна Білоус та Веніамін Михайлович Кляровський [3] вивчали прояви грязьового вулканізму на Старуні протягом 1977-1988 pp. Їхні дослідження посприяли реєстрації цієї ділянки площею 60 га як геологічної пам'ятки природи загальнодержавного значення під назвою «Старуня», що охороняється місцевою владою. Геологічну пам'ятку природи «Старуня» створено постановами Ради Міністрів Української РСР від 21 березня 1984 року № 139 та Кабінету Міністрів України від 12 жовтня 1992 року № 583, а положення про пам'ятку затверджено наказом Міністерства екології та природних ресурсів України від 11 листопада 2014 року № 360.

У 1977-1980 pр. до вивчення Старуні долучились геологи О. М. Адаменко, О. Р. Стельмах, Г. Д. Стельмахович, Н. М. Шевчук, В. В. Колєнченко та інші співробітники кафедри загальної геології ІФНТУНГ $[1,2]$. До них приєднались палеонтологи Природознавчого музею АН України (м. Львів) Д. М. Драгант та інші [12]. У той же період археолог Інституту українознавства ім. I. Креп'якевича АН України Леонід Георгійович Мацкевий разом 3 археологами Івано-Франківського педагогічного інституту ім. В. Стефаника Б. А. Василенком та І. Т. Кочкіним провели розкопки навколо Старуні. Було виявлено кілька десятків стоянок давньої людини епох пізнього палеоліту, мезоліту та неоліту [5]. Це були стоянки наших предків - кроманьйонців, що у своєму розвитку вже досягли рівня Homo sapiens - людини розумної. Варто згадати, що у 1914 р. професор М. Ломніцький писав про круглий отвір у черепі волохатого носорога, поруч з яким був знайдений уламок дерев'яного списа із загостреним кінцем.

У 1988-1989 рр. Івано-Франківський інститут нафти і газу вперше офіційно організував на Старунському грязьовому вулкані держбюджетні науководослідні роботи за фінансування Міністерства освіти і науки України під керівництвом О. М. Адаменка. Безпосередніми виконавцями теми були О. Р. Стельмах, Л. М. Михальська, І. Р. Михайлюк та інші працівники кафедри загальної геології (з 1989 р. - теоретичних основ геології). Крім досліджень динаміки функціонування грязьового вулкану, була виконана детальна топографічна зйомка масштабу 1:10 000 (кафедра інженерної геодезії, завідувач д.г.-м.н., професор Л. Я. Сайдаковський, безпосередній виконавець - к.т.н., доцент Р. Г. Пилип'юк), а також радіометрична зйомка (кафедра геофізики, завідувач - д.т.н., професор Б. Г. Тарасов, безпосередній виконавець - к.Г.-м.н., доцент В. П. Степанюк). Максимальні показники радіації у 60 мкр/год. (у 4-5 разів вище ГДК) зафіксовані біля свердловини «Надія», де і нині горить газ [2].

Наближення дати 100-літнього ювілею (2007 р.) палеонтологічних знахідок у Старуні призвело до активізації міждисциплінарних досліджень. Вийшла 
3 друку монографія краківського професора Штефана Александровича «Старуня» [8]. Президент польського товариства «Геосфера» професор Краківської гірничо-металургійної академії ім. С. Сташиця Мацей Котарба запропонував професору Олегу Адаменку, який усі роки (з 1977 і донині) продовжував вивчати Старуню як ендогеодинамічний полігон, розпочати спільні дослідження усіх процесів на цьому полігоні.

У 2004 р. були організовані дві українсько-польські експедиції (перша - у травні, а друга - у жовтні) за рахунок бюджетного фінансування Міністерства освіти і науки Польщі. На жаль, паралельний проект фінансування ІФНТУНГ не був підтриманий з боку аналогічного міністерства України. Результати досліджень обох експедицій опубліковані у 2005 р. у книзі «Polish and Ukrainian geological studies (2004-2005) at Starunia - the area of Discoveries of Wolly Rhinoceroses» за редакцією проф. М. Котарби [14]. Були висвітлені питання історії досліджень Старуні, охарактеризовані колекції палеонтологічних знахідок, археологічні дані, історія пошуків нафти та геологічної позиції місцезнаходження мамонтової фауни, роль покладів солі міоцену у формуванні структури надр, геоморфологічна та неотектонічна ситуація, голоценові тераси р. Великий Лукавець, осадові породи та дендрохронологія захоронених дерев, а також розпочатих тоді широких геофізичних та геохімічних досліджень і визначень абсолютного віку радіокарбоновим методом. Тоді ж вперше була опублікована ідея О. М. Адаменка про створення у Старуні Парку Льодовикового періоду [2].

У 2005 р. була проведена наукова конференція у Кракові, а у 2008 р. в Івано-Франківську. Вони були присвячені 100-річчю палеонтологічних знахідок, 3 екскурсіями до Старуні, 3 широким обговоренням наукових результатів експедицій 2004-2005 рр. та їх висвітленням у кількох збірках матеріалів та засобах масової інформації.

Черговий етап міждисциплінарних досліджень Старуні відбувся у 20062009 рр., коли під керівництвом професорів М. Котарби та О. Адаменка вдалось організувати буріння кількох десятків свердловин зі 100-відсотковим відбором керну для детального вивчення четвертинних відкладів. Продовжувались також геолого-геоморфологічні, геохімічні, геофізичні дослідження, особливо важливим було визначення ізотопів вуглецю у вуглеводневих сполуках 3 метою встановлення природи вуглецю: чи «прийшов» він 3 глибин разом 3 нафтою, чи утворився при перетворенні четвертинних органічних решток мамонтової фауни та тундрової флори.

Результати цих досліджень опубліковані у науковій збірці «Interdisciplinary studies (2006-2009) at Starunia (Carpathian region, Ukraine) - the area of discoveries of Wolly Rhinoceroses» (Annales Societatis Geologurum Poloniae, vol. 79, no. 3, Krakow, 2009: С. 217-480). Основні досягнення викладені у 17 статтях і стосуються геологічного середовища, геоморфології, літології, стратиграфії та палеогеографії верхньоплейстоценових та голоценових відкладів, їх палінологічної палеоботанічної характеристики, радіокарбонового датування, опису макрорешток рослин та фауни мушлів, хроностратиграфії та змін довкілля за період пізнього плейстоцену і голоцену, a також досліджень методами електрозондування, гравірозвідки i мікрогравіки, геохімічних аналізів газів, ізотопів вуглецю, мікробіологічної характеристики четвертинних відкладів та бітумів [15]. 
Важливим результатом було виявлення найсприятливішої ділянки, де могли на глибині зберігатися ще не знайдені рештки велетенських ссавців і навіть кроманьйонців плейстоцену. Локалізовано місцезнаходження конкретних колонкових свердловин, пробурених у 2007-2008 pр., де товщина захоронених боліт плейстоцену досягає 2 м і де $\epsilon$ достатня кількість консервантів (солі та бітуму). Тому пошуки волохатих носорогів та мамонтів повинні бути продовжені буровим та кар'єрним способом [2].

32016 p. i донині тривають польові дослідження Старунського геодинамічного полігону геологами ІФНТУНГ Т. В. Калиній, В. Г. Омельченком, Г. Д. Стельмахович, М. І. Мосюком, Д. О. Зоріним, К. О. Радловською разом з майбутніми магістрами - геологами та екологами під керівництвом професора О. М. Адаменка. Виконано дешифрування космічних та аерофотознімків, а також знімків з малих висот з використанням безпілотного дрона. Відібрані проби на визначення забруднювачів у геологічному середовищі, грунтах, поверхневих водах, опадах снігу та рослинності. Результати цих робіт викладені у пропонованій статті.

\section{Виклад основного матеріалу}

Старунський геодинамічний полігон - геологічна пам'ятка природи «Старуня» (рис. 1) розташована на площі 60 га на південно-західній околиці с. Старуня Богородчанського району Івано-Франківської області. Це - територія розробки озокеритового родовища, яку називали «Фабрика» або «Ропище». У тектонічному відношенні полігон відноситься до Бориславсько-Покутської зони Передкарпатського прогину - основного нафтопромислового регіону Карпатської нафтогазоносної провінції. Більш детально - це апікальна частина Старунської антиклінальної складки, яка після геологорозвідувальних робіт виявилась несприятливою для видобутку нафти або газу.

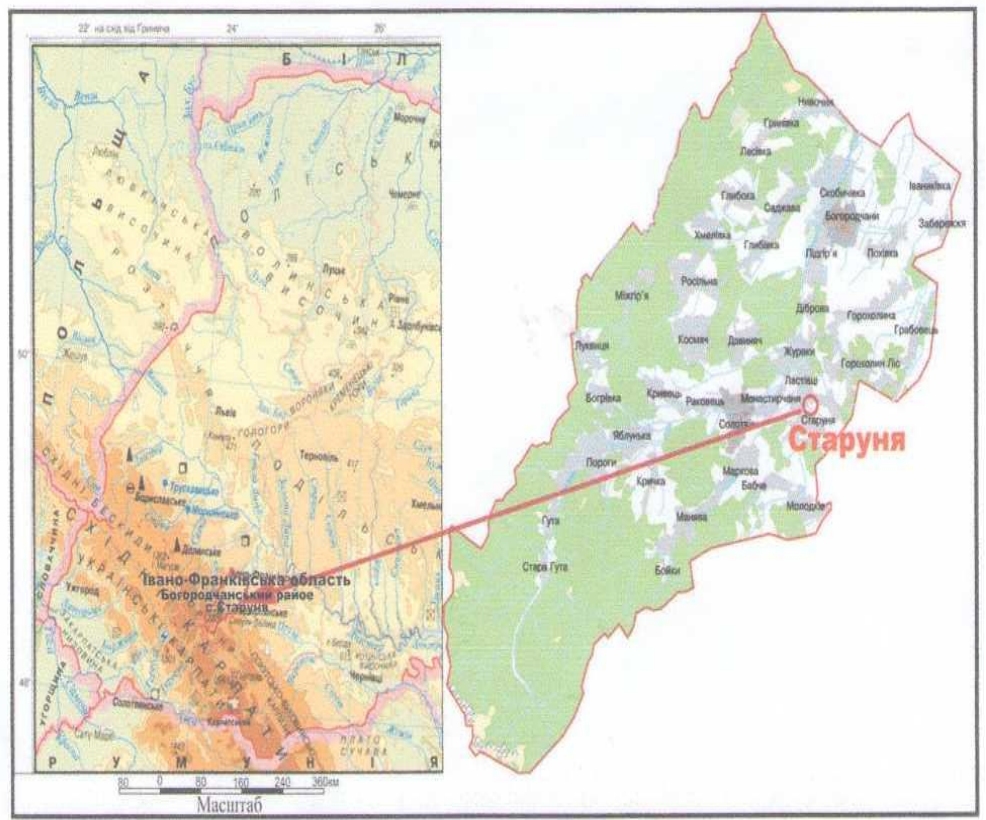

Рис. 1 - Оглядова карта розміщення Старунського геодинамічного полігону та грязьового вулкану 
Геологічний розріз дочетвертинних відкладів Старунської складки представлений (знизу вверх):

- флішова товща верхньої крейди - нижнього міоцену - багаторазове ритмічне чергування пісковиків, алевролітів, аргілітів різного кольору (стрийська та менілітова світи);

- моласова товща міоцену - пісковики, алевроліти, зцементовані солями, часто перетвореними у брекчію, просіченою жилами озокериту (воротищенська світа).

Четвертинні відклади Старунського місцезнаходження були у центрі уваги дослідників у останні роки. Геологи та екологи ІФНТУНГ Т. В. Калиній, В. Г. Омельченко, Г. Д. Стельмахович, М. І. Мосюк, Д. О. Зорін, К. О. Радловська під керівництвом О. М. Адаменка вперше побудували техногеологічну карту та схему взаємовідношень плейстоценових утворень (рис. 2) [7].

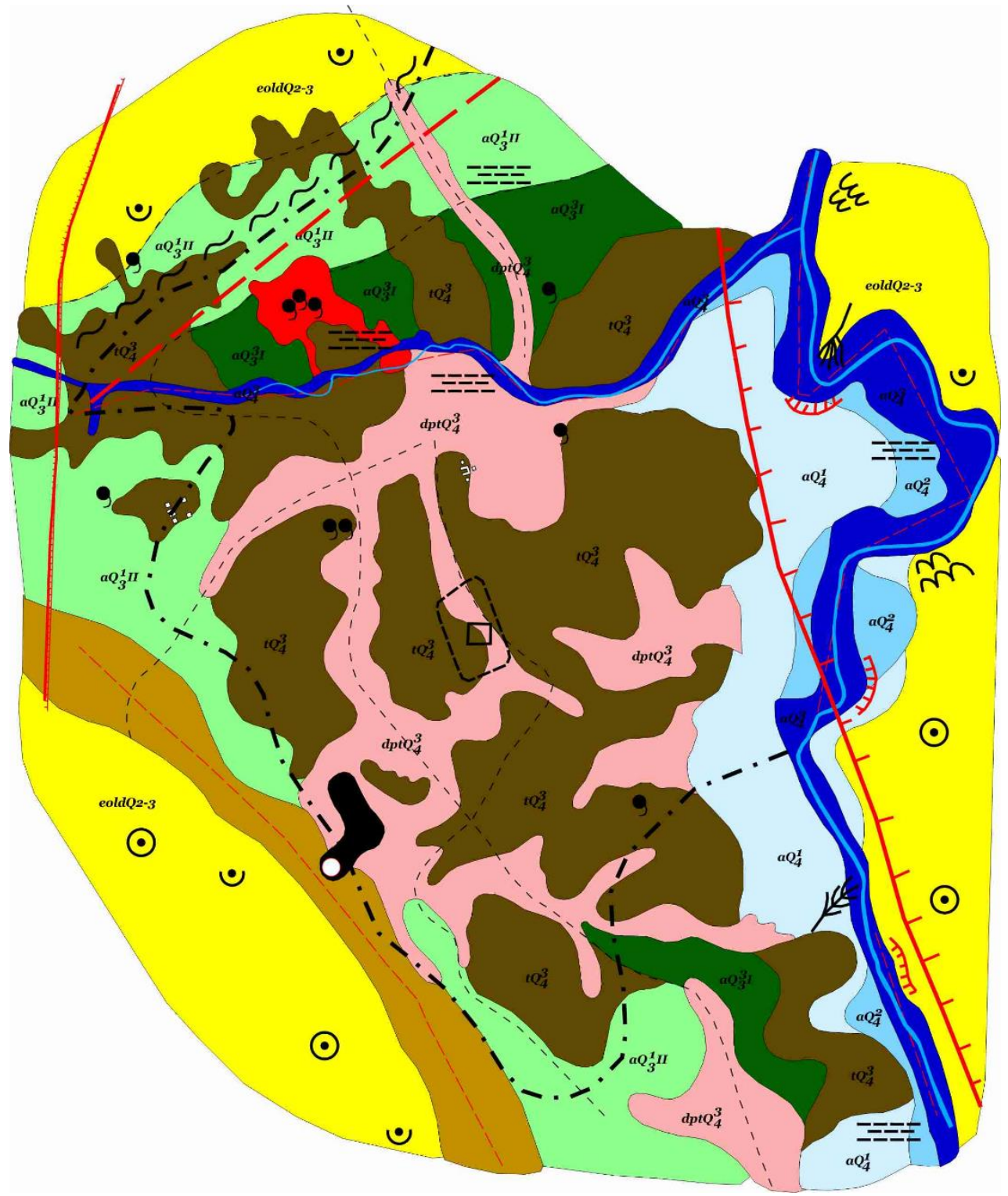




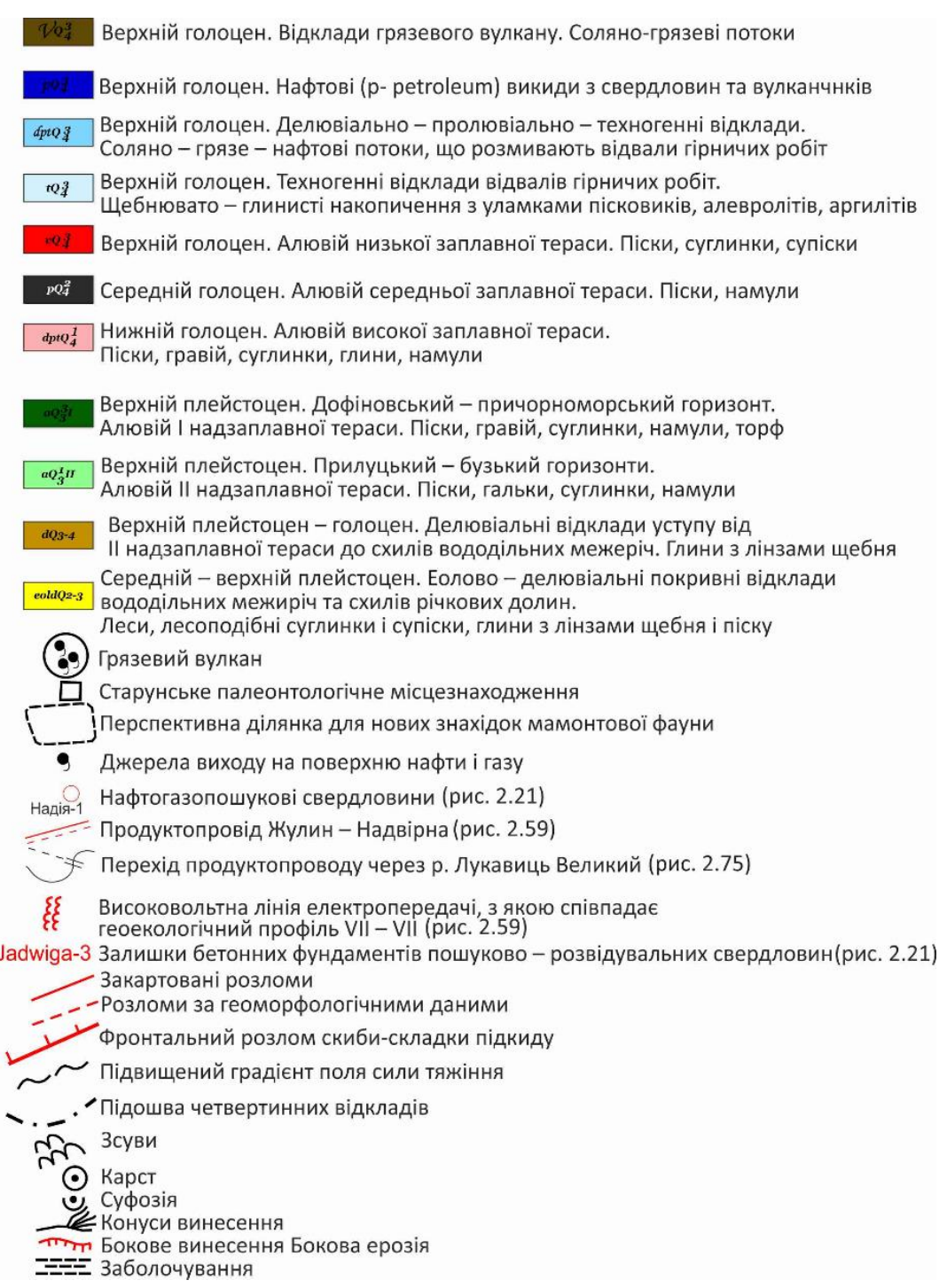

Рис. 2 - Техногеологічна карта Старунського геодинамічного полігону

Південно-західну частину території пам'ятки займає схил вододілу. Такий же схил розташований вздовж східного кордону полігону. Між ними - долина p. Луковець Великий. Схили складені середньо-верхньоплейстоценовими еолово-делювіальними eoldQ2-3, так званими покривними відкладами вододільних межиріч та схилів річкових долин. Вони представлені 5-15-метровими товщами лесів, лесоподібних суглинків та супісків, глин 3 лінзами щебеню та піску.

У підніжжі схилу вузькою смугою розвинуті верхньоплейстоценголоценові делювіальні відклади $\mathrm{dQ}_{3-4}$, що відділяють схил вододілу від поверхні II надзаплавної тераси $\mathrm{aQ}_{3} \mathrm{II}$, яка складена русловими гальковиками та пісками і заплавними намулами.

Перша надзаплавна тераса $\mathrm{aQ}_{3} \mathrm{I}$ представлена русловими гальковиками 3 тонкими лінзами намулів, часто бітумізованих, торфу та суглинків 3 включеннями гальки. У низах I тераси, серед 1-2-метрової товщі давнього 
болота, у шахті (копальні) №4 (мамонтова) знайдені муміфіковані рештки волохатих носорогів та мамонта. Вік I тераси визначено як друга половина пізнього плейстоцену (дофіновський та причорноморський горизонти) $[6,11]$.

Голоценова частина розрізу Старуні представлена алювієм трьох заплавних терас: $\mathrm{aQ}_{4}{ }^{1}$ - нижній голоцен, висока заплава, піски, гравій, суглинки, глини, намули, товщиною до 2-3 м; $\mathrm{aQ}_{4}^{2}-$ середній голоцен, середня заплава, піски, намули товщиною $0,5-1 \mathrm{~m} ; \mathrm{aQ}_{4}{ }^{3}-$ верхній голоцен, низька заплава, піски, суглинки, супіски товщиною $0,5-1$ м.

Переходимо до характеристики спорово-пилкових (палінологічних) діаграм, які визначають вік четвертинних відкладів. За даними R. StachowiczRybka, W. Granoczewski, F. Hynowecka-Czmielewska [19], які аналізували проби, а відбір їх виконували аналітики та Г. Д. Стельмахович, М. І. Мосюк під керівництвом О. М. Адаменка.

\section{Методи дослідження}

Матеріали для палінологічних досліджень відібрано восени 2007 та навесні 2008 pp. шляхом буріння понад 40 свердловин діаметром 6-12 см. Палінологічні аналізи проведено для трьох свердловин 4', 22 і 28 та відслонення VL - 1 (рис. 3-6).

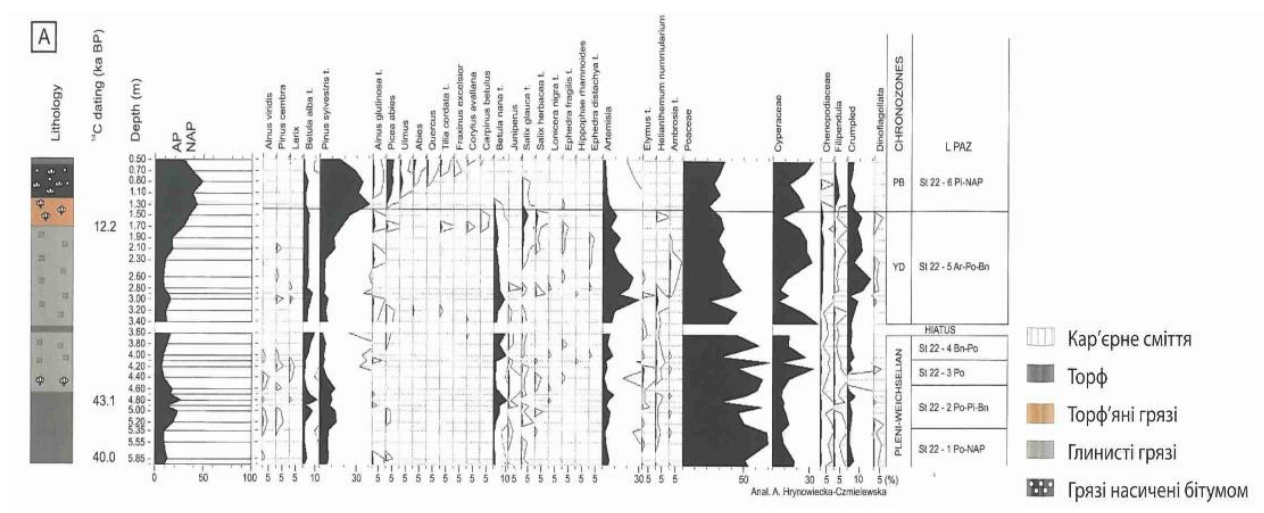

Рис. 3

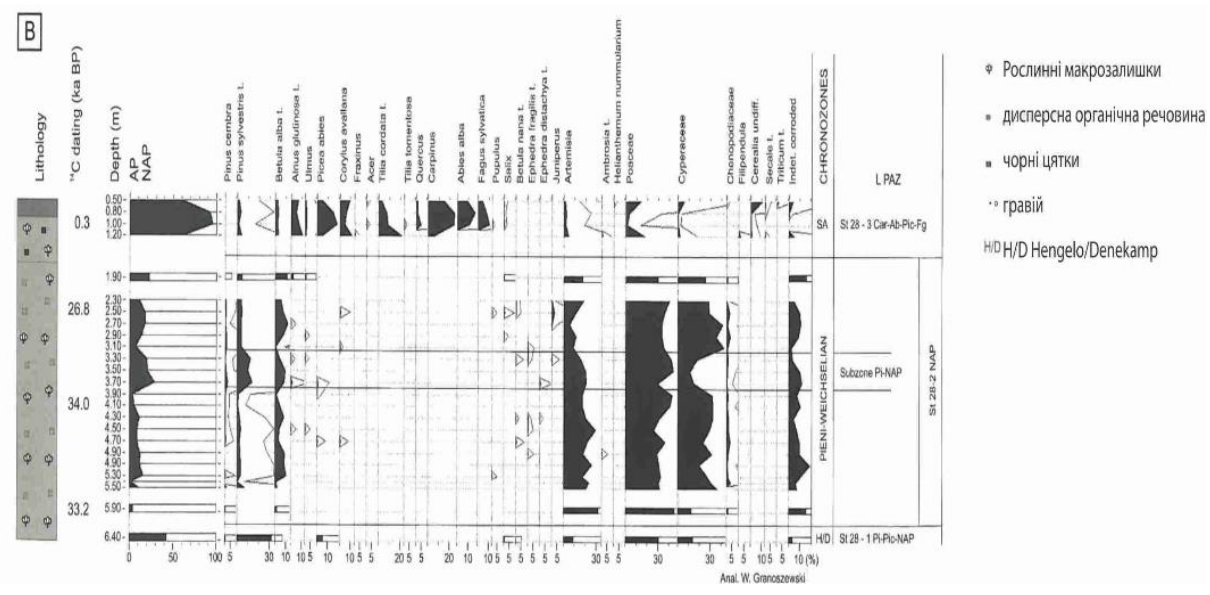

Рис. 4 


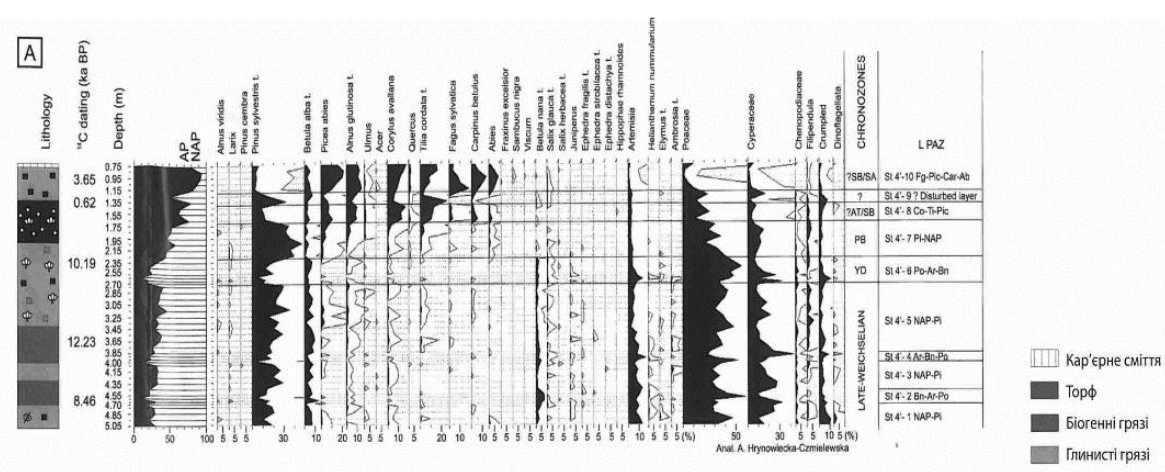

Рис. 5

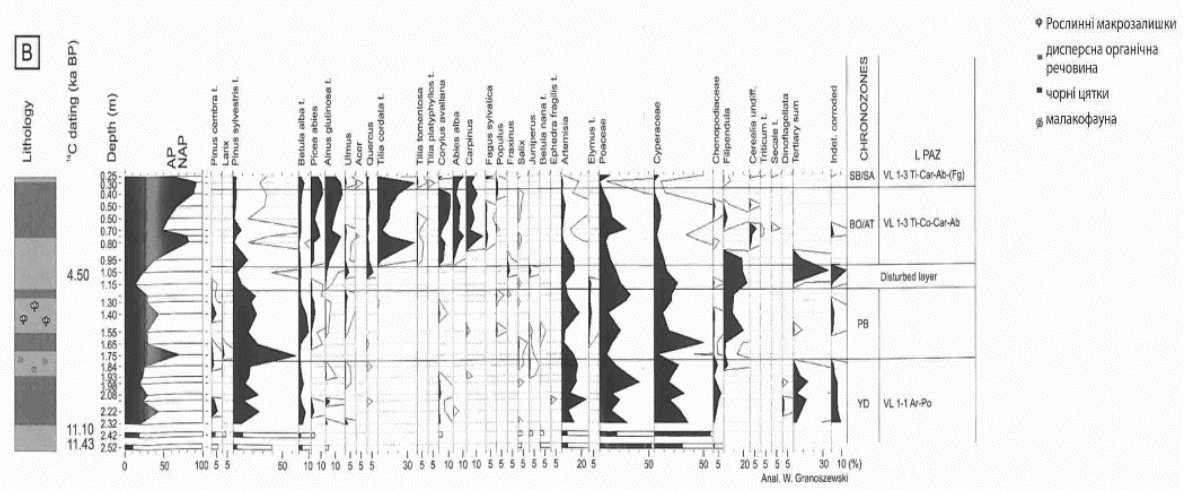

Рис. 6

Рис. 3-6 - Палінологічні діаграми [15, 19]

Зразки макроскопічних рослинних решток відібрано так, що кожен такий зразок для аналізу пилку брали із середини 10-сантиметрового розрізу (Stachowicz-Rybka та ін., 2009) [19]. Процес лабораторної підготовки відкладів до аналізу (1 $\left.\mathrm{cm}^{3}\right)$ охоплює два етапи. Перший - це видалення бітумів. Здрібнені зразки занурено у нетоксичний поверхнево-активний реагент Rokanol DB7 i промито 10\% розчином етанолу. Мацерація зразків забезпечила відокремлення пилкових зерен одне від одного. Другий етап - це додавання індикатора (спори лікоподій Lycopodium spores) та обробка 10\% хлоридною кислотою (хлороводень НСІ). Щоб видалити гумінові кислоти, зразки прокип'ятили у $10 \%$ розчині гідроксиду калію $(\mathrm{KOH})$. Згодом їх промили у воді понад десять разів. У випадку, коли зразки відкладів дуже сильно просочені бітумом, промивання Rokanol DB7 повторювали. Відокремлення спороморфів (викопні спори, пилкові зерна) від мінеральних компонентів здійснено флотаційним методом. Підкислений осад оброблявся розчином хлорид цинку $\left(\mathrm{Z}_{\mathrm{n}} \mathrm{Cl}_{2}\right)$ густиною 1,98 г/мл і центрифугувався протягом 20 хвилин при 2000 об/хв. Після використовували метод Ердтмана: промивка спиртом, обробленим безводним гліцерином.

Пилкові зерна погано збережені - загальна кількість від 100 до 600 і більше. В основному це - дерева, кущі, пилок наземних рослин. Спори та пилок місцевої рослинності розраховано щодо основної кількості. Пилкові діаграми побудовані за допомогою комп'ютерної програми POLPAL для Windows (рис. 3-6). 


\section{Аналіз результатів}

Палінологічний аналіз дозволив визначити стадії розвитку рослинності епохи Вейхселівського зледеніння (Віслінський період) (Pleni-Weichselian) пізнього плейстоцену (Late Glacial) і голоцену (Holocene) (табл. 1). Найдавніші з них зафіксовано у геологічних розрізах свердловин 22 і 28.

\section{Пізній Плейстоцен}

Епоха Вейхселівського зледеніння (Pleni - Weichselian). Радіовуглецеве датування органічних відкладів із нижньої частини розрізу свердловини 22 (глибина 5,85 м) показало $40000 \pm 700$ років до сучасності, а зразок з глибини 4,8 м, датується як $43100 \pm 700$ років до сучасності. Отримані дати дають змогу віднести нижню частину геологічного розрізу до середини епохи Pleni Weichselian (Behre, 1989) [10].

Стадіальна фаза Lattrop середнього Pleniglacial. Свердловина 22 - зразок 1 (глибина 5,85-5,35 м).

Початок наступного інтерстадіалу Hengelo. Свердловина 22 - зразок 4 (глибина 4,10-3,90 м) (табл. 1). Цей рівень охоплює початок чергових кліматичних змін в бік потепління. Зменшення тундрових рослин берези карликової, осокових, а також збільшення дерев - берез сигналізують про зволоження клімату. Можливо, це початок нової інтерстадіальної епохи Hengelo.

Таблиця 1 - Стратиграфічна схема пізнього плейстоцену (Weichselian) Західної Свропи [10]

\begin{tabular}{|c|c|c|c|c|c|}
\hline \multicolumn{4}{|c|}{ Хроностратиграфія } & $\begin{array}{l}\text { Вік початку, } \\
\text { тис. років }\end{array}$ & $\begin{array}{c}\text { Киснево-ізотопні } \\
\text { зони, OIS }\end{array}$ \\
\hline \multicolumn{4}{|c|}{ Stadial Interstadial } & \multirow{4}{*}{$\begin{array}{c}10.2 \\
13.0 \\
28\end{array}$} & \multirow{2}{*}{ 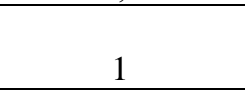 } \\
\hline \multicolumn{4}{|c|}{ Holocene } & & \\
\hline \multirow[b]{3}{*}{ 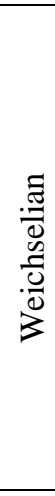 } & & LATE & $\begin{array}{l}\text { Younger Dryas Bölling - } \\
\text { Allered }\end{array}$ & & \\
\hline & \multirow[b]{2}{*}{$\begin{array}{l}\frac{. \pi}{0} \\
\frac{\pi}{0.00} \\
. \overline{0} \\
\frac{0}{2}\end{array}$} & LATE & & & 2 \\
\hline & & MIDDLE & $\begin{array}{lr}\text { Hunnelorg } & \text { Denecamp } \\
\text { Hasselo } & \text { Hengelo } \\
\text { Lattrop } & \text { Moershoofd } \\
\text { Ebersdorf } & \text { Glinde } \\
& \text { Oerel }\end{array}$ & 59 & 3 \\
\hline & & EARLY & Schalkholz & 70 & \\
\hline & \multirow{2}{*}{\multicolumn{2}{|c|}{ ERLY }} & $\begin{array}{ll} & \text { Oddreade } \\
\text { Rederstall } & \end{array}$ & 13 & 4 \\
\hline & & & Heming Brorup & 11 & $5 \mathrm{a}-\mathrm{d}$ \\
\hline \multicolumn{4}{|c|}{ Eemian } & 129 & $5 \mathrm{e}$ \\
\hline
\end{tabular}


Інтерстадіал Hengelo. Свердловина 28 - зразок 1 (глибина 6,40 м). Пилкові спектри [19] відображають безлісовий відкритий ландшафт. Домінування рослинних угрупувань пасовищного типу підтверджено високою часткою пилку злакових (Poaceae), полину (Artemisia), лободових (Chenopodiaceae) та інших трав'янистих рослин. Вологіші місця займали карликові чагарники тундри, де росли береза карликова (Betula nana), вільха зелена (Alnus viridis), осокові (Cуреraceace). Зафіксовані залишки цанікелії болотної (Zannichellia palustris) та жовтецю водного (Batrachium sp.) свідчать про мілководдя евтрофних водойм. Простежено очеретяне угрупування, рогіз (Typha sp.), ситник (Juncus sp.), а на вологіших або замулених тимчасово пересихаючих ділянках берегів виявлено рештки череди трироздільної (Bidens tripartita).

Інтерстадіал Moershoofd. Свердловина 22 - зразок 2 (глибина 5,35-4,60 м) (табл. 1). Помітне поширення сосни та берези передувало розповсюдженню карликової чагарникової тундри і відображає потепління. Спочатку відбулося збільшення вологи з подальшим підвищенням температури. Свідченням цього $\epsilon$ поява серед водних угрупувань рдесту ниткоподібного (Potamogeton filiformis), а також розвиток на вологих та торфових болотних ділянках тризубця морського (Triglochin maritimum), ситнягу болотного (Eleocharis palustris), ситнику (Juncus sp.) і численних видів осоки (Carex). Ймовірно, що період поліпшеного клімату тривав недовго, про що свідчить невелике збільшення частки пилку сосни та берези [19].

Стадіальна фаза Hasselo. Свердловина 22 - зразок 3 (глибина 4,40-4,10 м) (табл. 1). Похолодання 3 домінуванням степових угрупувань виражено збільшенням злакових і ялівцю (Juniperus) й зниженням пилку сосни і берези, відображаючих існування арктичного клімату з континентальним впливом. Про це також свідчить зникнення водних рослин та збіднення рослинності на вологих ділянках як за кількістю, так і за видовим складом.

Цей рівень характеризується розвитком лісостепових угрупувань, де переважають сосна звичайна (Pinus sylvestris) і ялиця (Picea). Степові угрупування домінували в ландшафті, що підтверджено появою трав й осок. Наявність пилку осокових й берези карликової свідчить про появу тундрових угрупувань наступного стадіалу Hunnelorg.

Інтерстадіал Denecamp. Свердловина 28 - зразок 2 (глибина 5,90-1,90 м) (табл. 1) [15, 19]. Накопичення відкладів відбувалося в умовах відкритого ландшафту. Степові угрупування представлені травою, бур'янами типу полин, а також низкою трав'янистих: лободові, ефедри (Ephedra fragilis та Ephedra distachya L.). Ділянки підвищеної вологості зайняті залишковою рослинністю тундри, включаючи березу карликову та осокові. Деревна рослинність представлена деревами берези. Спостерігаємо незначне збільшення сосни звичайної. Така зміна рослинності була наслідком потепління та сухості клімату. Радіовуглецеві датування: 33,2; 34,0; 26,8 тис. р. [15].

Інтерстадіал Alleröd. Свердловина 4' - зразки 1-5 (глибина 5,05-2,75 м) (табл. 1) [19]. Потепління у річковій долині Великий Лукавець розпочинається зі зменшенням відкритих ареалів степових та степово-тундрових угрупувань. Поширення злакових та полину, а також представників родини айстрових (Asteraceae) і сонцесвіту звичайного (Helianthemum nummularium) стало характерним для угрупувань й засвідчує наявність сухого, континентального клімату. Окрім того, відкритість ландшафту підтверджено наявністю ялівцю, ефедри (Ephedra fragilis, E distachya, E strobilacea) і обліпихи звичайної 
(Hippophae rhamnoides). Тундрові угрупування залишались на висотах рельєфу i представлені березою карликовою, осоковими разом із плаунком плауноподібним (Selaginella selaginoides) i плаунчиком швейцарським (Selaginella helvetica). Сосна та береза, ймовірно, утворювали бореальні ліси, у яких зустрічаємо й модрину та ялину. Частка останніх значно зросла у молодшій (верхній частині інтерстадіалу). Жовтець водний свідчить про водне походження відкладів, а також про теплі кліматичні умови в кінці аллереду. У воді росли рдест ниткоподібний і цанікелія болотна. На берегах були очеретяні угрупування, де також спостерігаємо осокові та ситняг.

Варто зауважити, що помітне поширення степово-тундрових рослинних угрупувань спостерігаємо у зразку 4 (глибина 4,0-3,90 м), що пов'язано 3 наближенням Пізнього Дріасу. У розрізі свердловини 4, розташованої на відстані менше 2 м від свердловини 4', відклади відповідної глибини виступають показниками холодного клімату та заболочених місць, типових для Пізнього Дріасу. Радіовуглецева дата (12, 23 тис. р.) - зафіксована на глибині 3,5 м розрізу 4.

\section{Голоцен}

Похолодання Пізній Дріac (Younger Dryas). Свердловина 4' - зразок 6 (глибина 2,70-2,35 м). Свердловина 22 - зразок 5 (глибина 3,40-1,5 м). Відслонення VL - 1, зразок 1 (глибина 1,52 - 1,84 м) [19]. Охолодження клімату призвело до поширення степових та степово-тундрових рослинних угрупувань 3 домінуванням злакових, осокових, полину і лободових. Степовий характер засвідчують пирійник (Elymus), сонцесвіт звичайний і представники родини айстрових Asteraeae (пилок амброзії Ambrosia, айстри Aster, ромену Anthemis), цикорієві (Cichorioideae). Поширеність берези карликової, верби трав’яної і трав'янистих рослин підтверджують наявність карликової чагарникової тундри. Деревний пилок, ймовірно, транспортовано 3 дальших відстаней. Модрина (Larix), вільха зелена, сосна кедрова європейська (Pinus cembra), ялівець, обліпиха звичайна, чорноплідна жимолость (Lonicera nigra), ефедра двоколоса (Ephedra distachya) і (Ephedra fragilis) трапляються спорадично. $\mathrm{У}$ верхній частині розрізу частка сосни і ялівця зростає, що свідчить про незначне збільшення деревного покриву й покращення клімату, зокрема вологості. У мілкому водоймищі росте цанікелія болотна, жовтець, а також очерет, що домінує над рогозом.

Пребореальний період (Preboreal). Свердловина 4' - зразок 7 (глибина 2,25-1,75 м). Свердловина 22 - зразок 6 (глибина 1,30-0,50 м). Відслонення VL - 1, зразок 2 (глибина 1,84 - 1,25 м) [19]. Поліпшення клімату спричинило швидке поширення лісових угрупувань із домінуванням сосни звичайної, ялини і модрини. Починають з'являтися термічно вимогливі дерева, такі як: в’яз (Ulmus), дуб (Quercus ), липа дрібнолиста (Tilia cordata), вільха чорна (Alnus glutinosa) і ліщина звичайна (Corylus). Невелика частка пилку ялиці білої (Abies alba) свідчить про транспортування пилку 3 дальших відстаней. Такі рослинні таксони підтверджують початок лісових зон. Угрупування відкритої рослинності 3 травами, родиною лободових ще поширені, але супроводжуються збільшенням кількості гадючника (філіпендула Filipendula), птеридорфітів (Filicales monolete), а також осокових. Це указує на вологолюбні рослинні угрупування. 
Бореальний і Атлантичний період Boreal and Atlantic. Свердловина 4' зразок 9 (глибина 1,65-1,45 м). Відслонення VL - 1, зразок 3 (глибина 1,25-0,40 м) [19]. Домінування лісових угрупувань 3 ліщиною звичайною i липою дрібнолистою указують на поліпшення клімату та подальшу стабілізацію рослинних зон. Зауважимо, у деревостанах передгірної зони виявлено чималу частку липи. В'яз, дуб і граб (Carpinus) свідчать про рідкісні змішані листяні ліси. Річкові долини зайняті рослинними угрупуваннями, представленими вільхою чорною, гадючником, осоковими і багатоніжковими у підліссі. Нижню лісову зону представлено буком (Fagus) і ялицею, а верхню ялиною. Відкриті рослинні угрупування низькопродуктивні, але присутні. Основні компоненти представлено злаковими і полином. Виявлено пилок зернових культур (культурних злаків), а саме: пшениці (Triticum) і жита (Secale).

Суббореальний період Subboreal. Свердловина 4' - зразок 5 (глибина 1,65-1,45 м). Відслонення VL - 1, зразок 4 (глибина 0,40-0,25 м) [19]. Ймовірно, що у цей період відбулося формування гірських лісових зон, які нагадують сучасні. У передгірській зоні домінують липа й граб, а також зустрічається ліщина звичайна, клен (Acer), ясен (Faxinus) і липа широколиста. У підліссі переважають бузина чорна (Sambucus nigra) i крушина ламка (Fangula). На вологих ділянках росте вільха. Виявлено тис (Taxus), вербу і ясен. Буково-ялицеві ліси утворювали нижню гірську зону, а хвойні дерева верхню. Присутні сліди вирощування зернових культур. Радіовуглецеве датування $-625 \pm 50$ років [15].

Субатлантичний період Subatlantic. Свердловина 28 - зразок 2 (глибина 5,90-1,90 м) [15]. Субатлантичний період характеризується відкритістю ландшафту, яка виражена збільшенням пилку трав'янистих рослин, зокрема полину, злакових культур, включаючи пшеницю, жито, гречку (Fagopyrum). Виявлено низку рослинних таксонів, пов'язаних із діяльністю людини, наприклад: подорожник ланцетолистий (Plantago lanceolata), подорожник великий (Plantago maior), подорожник середній (Plantago lmedia), спориш звичайний (Polygonum aviculare).

\section{Порівняння результатів 3 іншими регіонами}

У південно-східній частині Польщі віслінські відклади не вивчені. У басейні річки Дністер (Галицький район) є декілька розрізів лесів і викопних грунтів, палеозоїв, вік яких охоплює інтервал від раннього віслінського до історичного часу (Komar, 2002) [13], (Boguckyj \& Lanczont, 2002) [11]. У верхніх шарах Єзупільського розрізу зафіксовано зміни рослинності, які вказують на послідовність подій Weichselian Interpleniglacial у вигляді інтерстадіальних бурих грунтів. Результати палінологічних досліджень показують, що після періоду панування трав'янистих рослин, у тому числі ксерофітів і галофітів, у цьому регіоні розпочинається розвиток розрідженого соснового лісу 3 невеликим компонентом листяних дерев. Розріз відповідає грунтовому горизонту Дубно. Геоморфологічний аналіз Колодіївського розрізу (Boguckyj \& Lanczont, 2002) [11] дав змогу описати детальну стратиграфію Interpleniglacial. Виокремлено два рівні субарктичних бурих грунтів, а саме: Дубно 2 - старіший, і Дубно 1 - молодший, який виник у міжстадіальних умовах. Виявлено також шар лесів, який їх відокремлював і розвивався 
у стадіальних умовах. Окремі пласти басейну р. Дністра у Галицькому районі відповідають середині Weichselian Pleniglacial.

У розрізі з Жохова поблизу Мелека (Srodon, 1976) [18], де знайдено скелет мамонта (Mammuthus trogontherii), датованого 50000 - 56000 років до сучасності, лісостеп відповідає періоду Brörup Interstadial (Early Weichselian). У ландшафті переважають рідкісні соснові ліси, ялівець та угрупування трав'янистого степового типу 3 численними світлолюбними рослинами. У долині річки росли вільхи, сосни, ялини, берези і хміль звичайний (Humulus Lupulus).

Розріз села Бжезьниця (Brzeźnica, Польща) на p. Віслока (Wisłoka), яке розташоване у 15 км від Rzochów (Mamakowa \& Staekel, 1974) [16], також представлено лісостеповим ландшафтом, а відклади датовано $35965 \pm 1000$ років до сучасності - Hengelo Interstadial (Brzeznica В) та $27990 \pm 1415$ років до сучасності - Denekamp Interstadial (Brzeznica A). Серед домінуючих рослин сосна кедрова європейська, модрина, ялівець, також виявлено ефедру двоколосу. Угрупування карликових тундрових чагарників 3 березою карликовою і вербою полярною (Salix polaris), а також злакові та полин відіграють значну роль. Як у Старуні, так і в Бжезьниці відклади голоцену лежать вище Віслінського періоду (Pleni - Weichselian). Стовбур граба датовано суббореальним періодом (3,380 \pm 65 років до сучасності). У той час панували грабові ліси з дубом і буком, а в долині річки - вільхові ліси з липою і березами.

Низи відкладів с. Лазек (Łążek, Польща) поблизу Заклікува (Zaklików) на p. Санна (Sanna River) [19] датуються 25,580 (土 3 270-2 420) років до сучасності, що відповідає верхньому Віслінському періоду (upper Pleni Weichselian). Пилкові дослідження вказують на наявність рослинного покриву паркового типу тундри 3 погано диференційованими ділянками сосновомодринового лісу. Розвиваються степові угрупування 3 великою кількістю трав'янистих і світлолюбних рослин, наприклад: полин, лободові, ладанникові (Helianthemum oelandicum), льон австрійський (Linum austriacum) і ефера двоколоса.

Вік підошви торф'яних відкладів з Jasło Bryły (Польща) [17] датовано 45000 років до сучасності - Hengelo Interstadial, верхівка верхнього шару $34000 \pm 1000$ років до сучасності та $35,300 \pm 1,500$ років до сучасності. На території Ясло у Віслінському періоді (Pleni - Weichselian) переважає тундра парк із модриною, сосною кедровою європейською, ялівцем і подекуди вільхою зеленою, яка поступово перетворюється на відкритий ландшафт 3 домінуючими травами, осоками, світлолюбними рослинами, наприклад: ребро насінник гірський (Pleurospermum austriacum), сонцесвіт звичайний та ін. На вологіших ділянках зустрічається береза карликова, сосна кедрова європейська і модрина.

Найповніші палінологічні дані із с. Старуня мають аналоги у Бещадах. На територіях Вижня Тернава I i II (Tarnawa Wyżna, Польща) [19] представлено родинні угрупування раннього Дріасу (Older Dryas, Late Weichselian) субатлантичного періоду. У шарах Allerød переважають рідкісні соснові ліси 3 сосною кедровою європейською, модриною і ялівцем. Похолодання у Пізньому Дріасі призвело до панування відкритої рослинності з домінуванням трав. Серед продуктивних видів виявлено айстрові, а непродуктивних - сосна звичайна, сосна кедрова європейська, модрина і ялівець. Пребореальний 
період охарактеризовано збільшенням частки сосни й зменшенням трав'янистих рослин. У лісах бореального періоду панують в'яз, береза i вільха. В атлантичний період росли ліщина звичайна, дуб і липа дрібнолиста. Бук домінує, починаючи 3 суббореального і до субатлантичного періоду, разом із грабом і ялицею. Інші ділянки Бещад (Ralska - Jasiewi - czowa, 1980) описують рослинну послідовність від атлантичного періоду - територія Смерек і Заколе (Smerek, Zakole, Польща), суббореального періоду територія Смолник i Волосате (Smolnik, Wolosat, Польща), до субатлантичного періоду.

У пилкових розрізах с. Старуня виявлено відклади, які віднесені до бореального періоду, наприклад пилок ялиці. 3 одного боку, його низький відсоток $(<1 \%)$ свідчить про транспортування 3 дальших відстаней, але й місцеві насадження ялиці у цій частині Карпат не можна виключати. 3 іншого, поява такого пилку потребує детальнішого дослідження відкладів цього періоду на території України.

\section{Висновки}

Екологічні дані щодо четвертинних відкладів у межах річкової долини Великий Лукавець свідчать про окремі відповідності 3 даними, отриманими під час досліджень польських Карпат. Незначні відмінності, перш за все це домінування відкритих рослинних угрупувань, обумовлені географічним положенням, а також впливом більш континентальних кліматичних умов на рослинність досліджуваної ділянки.

Розвиток рослинних угрупувань Віслінського періоду (Pleni - Weichselian) як у холодніші (стадіали), так і тепліші періоди (інтерстадіали) чітко репрезентують розвиток рослинних співтовариств відомих як тундростеп, а також їхнє домінування у річковій долині Великий Лукавець на той час. Безсумнівно, що й у масштабі всієї площі Українських Карпат переважає тундростеп. Такий рослинний покрив характерний і для ділянок, де були знайдені ссавці епохи плейстоцену.

Історія розвитку рослинності у період голоцену на території Західної України у порівнянні з Польщею виявилась динамічнішою, що пояснюється близькістю до Карпатських і Балканських рефугіумів. Поширення липи, ялиці i буку було швидким і відбувалося майже одночасно, однак на території Польщі ці дерева з'являються значно пізніше, а їхнє поширення триває у межах довшого часового інтервалу.

\section{СПИСОК ЛІТРРАТУРИ}

1. Адаменко О. М. Старуня: Парк Льодовикового періоду / О. М. Адаменко, О. М. Карпаш, Д. О. Зорін, М. Й. Котарба, І. В. Мосюк, І. І. Ковбанюк. - ІваноФранківськ: Голіней О. М., 2017. - 212 с.

2. Адаменко О. М. Парк Льодовикового періоду / О. М. Адаменко, О. М. Мандрик, М. І. Мосюк, Д. О. Зорін, І. І. Ковбанюк. - Івано-Франківськ: Симфонія форте, 2019. $162 \mathrm{c}$.

3. Белоус Н. Х. Чудо - Старуня / Н. Х. Белоус, В. М. Кляровский // Геологические памятники Украины. - К.: Наукова думка, - 1987. - С. 48-49.

4. Екологічна енциклопедія: у 3 томах. - К.: Центр екологічної освіти та інформації, 2007. - T. 2: C- H. -417 c. 
5. Мацкевий Л. Г. Археологічні дослідження в Старуні: підсумки та перспективи / Л. Г. Мацкевий, Г. І. Панахид // Матеріали II Міжнародної наукової конференції до 100-річчя першої знахідки мамонта і волохатого носорога в Старуні у 1907 р. // В кн.: Викопна фауна і флора останнього зледеніння. - Краків: Akapit, 2007. - С. 25-28.

6. Матвіїшина Ж. М. Просторово-часова кореляція палеогеографічних умов четвертинного періоду на території України / Ж. М. Матвіїшина, Н. П. Герасименко, В. І. Передерій та ін. - Київ: Наукова думка, 2010. - 192 с.

7. Adamenko O. M. 2019. The Upper Pleistocene stratigraphy of the Starunya site as a «bridge» between the stratigraphical frameworks of Western Europe and the plain area of Ukraine. - Jornal of Geology, Geography and Geoecology, 28 (2): 213 - 220.

8. Alexandrowicz, S. W., 2004. Starunja and the Quarternary research in the tradifion and initiatives of the Polish Academy of Arts and Sciences. Studia I materialy do dziejoe Polskej Academii Umiejetnosczi. Polish Academy of Arts and Sciences. - Krakow, 3: 216 pp. (In Polish, English summary).

9. Bayger, J. A., Hoyer, H., Kiermik, E., Kulezynski, W., Zomnicki, M., Zomnicki, I., Mierzejewski, W., Niezabitowski, E., Raciborski, M., Szafer, W., Schille, F., 1914. Wykopaliska Starunskie. Muzeumim Dzieduszyckich wo Lwowie, 15: 386 pp. (In Polish only).

10. Behre, K. E., 1989. Riostatigraphy of the last glacial period in Europe. Quaternary Science Review. 8: 25 - 44.

11. Bogucki, A., Zanczont, M., 2002. Zoess stratigraphy in the Halič Prydnistrov'ja region. (In Polish, English summary): In: Madeyska, T. (ed.). Loess and Palaeolithic of the Dnister River Basin Halič Region (Ukraine). Studia Geologica Polonica, 119: 315 - 328.

12. Chernobay, Y. M., Drygant, D. M., 2009. The Starunia collections in the Natural History Muzeum of the National Academy of Sciences of Ukraine in Lviv. Geoturystyka, nz 3 (18): $45-50$.

13. Komar, M., 2002. Pollen analysis of the Upper Pleistocene loesses and paleosoils in the Yezupil and Halič sites. (In Polish, English summary). In: Madeyska, T. (ed.), Loess and Palaeolithin of Dnister River basis Halič Region (Ukraine). Studia Geologica Polonica, 119: $245-251$.

14. Kotarba, M. J. (ed), 2005. Polish and Ukrainian geological studies (2004-2005) at zhinoceroses. Polish Geological Institute and Society of Research on Environmental Changes «Geosphere», Warszawa - Krakow: 218 pp.

15. Kotarba, M. J. (ed), 2009. Interdisciplinary studies (2006-2009) at Starunia (Carpathian region Ukraine) - the area of discoveries of wooly zhinoceroses. Annales Societatis Geologorum Poloniae, 79 (3). - 217-480.

16. Mamakowa, K., Starkel, I., 1974. Wew data about the profile of Quatenary deposits at Bzzeznica on the Wisloka River the Carpathian Foreland. Studia Geomorphologia Carpatho - Balanica, 8: 47 - 53.

17. Mamakowa, K., Wojcik, A., 1987. Osady organiczne šrodkowego Vistulianu w Jasle Brytach (dolina Wisloki). (In Polish). Kwartalnik Geologiczni, 31: 213 - 214.

18. Srodon, A., 1976. Late Pleistocene Flora and mammonth skeleton from Rzochow near Miclec (Poland). Buletyn Peryglacialny, 26: 299 - 309.

19. Stachowicz-Rybka, R., Granoszewski, W., Hrynowiecka-Czmielewska, A., 2009. Quatarnary Environmental Changes at Starunia Palaeontological site and Vicinity (Carpathian region, Ukraine) based on Palaeobotanical studies. Annales Societatis Geologorum Poloniae, 2009, vol. 79: 279 - 288.

Стаття надійшла до редакиї 23.09.2019 і прийнята до друку після рещензування 17.10.2019 


\section{REFERENCES (TRANSLATED AND TRANSLITERATED)}

1. Adamenko, O. M., Karpash, O. M., Zorin, D. O., Kotarba, M. I., Mosuk, I. V., \& Kovbanuk, I. I. (2017). Starunia: Park Ljodovikovogo Periodu. Ivano-Frankivsk: Holiney O. M. (in Ukrainian).

2. Adamenko, O. M., Mandrik, O. M., Mosuk, I. V., Zorin, D. O., \& Kovbanuk, I. I. (2019). Park Ljodovikovogo Periodu. Ivano-Frankivsk: Simphonia forte. (in Ukrainian).

3. Belous, N. C., \& Kljarovskij, V. M. (1987). Chudo - Starunia. In Geologicheskie pamjatniki Ukrainy (pp. 48-49). Kyiv: Naukova Dumka. (in Russian).

4. Ekologicna enciklopedia u 3 tomah. (2007). K.: Centr ekologicnoi osviti ta informacii. (in Ukrainian).

5. Mackevij, L. G., \& Panachid, G. I. (2007). Archeologicni doslidjennia u Staruni. Materiali II Mishnarodnoi naukovoi konferencii do 100-richja perchoi znachidki mamonta i volohatogo nosoroga u Staruni 1907 r. (pp. 25-28). In: Vikopna fauna I flora ostannjogo zledeninnja. Krakiv: Akapit. (in Ukrainian).

6. Matviishina, I. M., Gerasimenko, N. P., Perederii, V. I. \& other. (2010). Prostorovochasova koreljacia paleogeographicnich umov chetverticnogo periodu na teritorii Ukraini. Kyiv: Naukova Dumka. (in Ukrainian).

7. Adamenko, O. M. (2019). The Upper Pleistocene stratigraphy of the Starunya site as a «bridge» between the stratigraphical frameworks of Western Europe and the plain area of Ukraine. Jornal of Geology, Geography and Geoecology, 28(2), 213-220.

8. Alexandrowicz, S. W. (2004). Starunja and the Quarternary research in the tradifion and initiatives of the Polish Academy of Arts and Sciences. In Studia I materialy do dziejoe Polskej Academii Umiejetnosczi. (pp. 216). Krakow: Polish Academy of Arts and Sciences. (In Polish, English summary).

9. Bayger, J. A., Hoyer, H., Kiermik, E., Kulezynski, W., Zomnicki, M., Zomnicki, I., Mierzejewski, W., Niezabitowski, E., Raciborski, M., Szafer, W., \& Schille, F. (1914). Wykopaliska Starunskie. Muzeumim Dzieduszyckich wo Lwowie, 15: 386 pp. (In Polish only).

10. Behre, K. E. (1989). Riostatigraphy of the last glacial period in Europe. Quaternary Science Review, 8, 25-44.

11. Bogucki, A., \& Zanczont, M. (2002). Zoess stratigraphy in the Halič Prydnistrov'ja region. In: Madeyska, T. (ed.). Loess and Palaeolithic of the Dnister River Basin Halič Region (Ukraine). Studia Geologica Polonica, 119, 315-328. (In Polish, English summary) 12. Chernobay, Y. M., \& Drygant, D. M. (2009). The Starunia collections in the Natural History Muzeum of the National Academy of Sciences of Ukraine in Lviv. Geoturystyka, 18(3), 45-50.

13. Komar, M. (2002). Pollen analysis of the Upper Pleistocene loesses and paleosoils in the Yezupil and Halič sites. In: Madeyska, T. (ed.), Loess and Palaeolithin of Dnister River basis Halič Region (Ukraine). Studia Geologica Polonica, 119, 245-251. (In Polish, English summary).

14. Kotarba, M. J. (Ed). (2005). Polish and Ukrainian geological studies (2004-2005) at zhinoceroses. Warszawa - Krakow: Polish Geological Institute and Society of Research on Environmental Changes «Geosphere».

15. Kotarba, M. J. (Ed). (2009). Interdisciplinary studies (2006-2009) at Starunia (Carpathian region Ukraine) - the area of discoveries of wooly zhinoceroses. Annales Societatis Geologorum Poloniae, 79 (3), 217-480.

16. Mamakowa, K., \& Starkel, I. (1974). Wew data about the profile of Quatenary deposits at Bzzeznica on the Wisloka River the Carpathian Foreland. Studia Geomorphologia Carpatho-Balanica, 8, 47-53.

17. Mamakowa, K., \& Wojcik, A. (1987). Osady organiczne šrodkowego Vistulianu w Jasle Brytach (dolina Wisloki). Kwartalnik Geologiczni, 31, 213-214. (In Polish).

18. Srodon, A. (1976). Late Pleistocene Flora and mammonth skeleton from Rzochow near Miclec (Poland). Buletyn Peryglacialny, 26, 299-309. 
19. Stachowicz-Rybka, R., Granoszewski, W., \& Hrynowiecka-Czmielewska, A. (2009). Quatarnary Environmental Changes at Starunia Palaeontological site and Vicinity (Carpathian region, Ukraine) based on Palaeobotanical studies. Annales Societatis Geologorum Poloniae, 79, 279-288.

The article was received 23.09.2019 and was accepted after revision 17.10.2019

\section{Адаменко Олег Максимович}

доктор геолого-мінералогічних наук, професор кафедри екології Івано-Франківського національного технічного університету нафти і газу. Заслужений діяч науки і техніки України, Лауреат Державної премії СРСР

Адреса робоча: Україна, м. Івано-Франківськ, вул. Карпатська, 15

ORCID ID 0000-0003-0821-3011

\section{Стельмахович Галина Дмитрівна}

асистент кафедри екології Івано-Франківського національного технічного університету нафти і газу

Адреса робоча: Україна, м. Івано-Франківськ, вул. Карпатська, 15

e-mail: o.stelmahovich@ukr.net

ORCID ID 0000-0003-3148-5402

\section{Мосюк Микола Іванович}

кандидат технічних наук, доцент кафедри екології Івано-Франківського національного технічного університету нафти і газу

Адреса робоча: Україна, м. Івано-Франківськ, вул. Карпатська, 15

e-mail: mosiuk@ukr.net

ORCID ID 0000-0002-9828-7331 